\title{
Activation of Group I Metabotropic Glutamate Receptors Produces a Direct Excitation and Disinhibition of GABAergic Projection Neurons in the Substantia Nigra Pars Reticulata
}

\author{
Michael J. Marino, ${ }^{1}$ Marion Wittmann, ${ }^{4}$ Stefania Risso Bradley, ${ }^{1}$ George W. Hubert, ${ }^{2}$ Yoland Smith, ${ }^{2}$ and \\ P. Jeffrey Conn ${ }^{3}$
}

Departments of ${ }^{1}$ Pharmacology and ${ }^{2}$ Neurology and Yerkes Regional Primate Research Center, Emory University, Atlanta, Georgia 30322, 3Merck Research Laboratories, West Point, Pennsylvania 19486, and 4Tierphysiologie, University of

Tuebingen, D-72076 Tuebingen, Germany

A pathological increase in excitatory glutamatergic input to substantia nigra pars reticulata $(\mathrm{SNr})$ from the subthalamic nucleus (STN) is believed to play a key role in the pathophysiology of Parkinson's disease. We present an analysis of the physiological roles that group I metabotropic glutamate receptors (mGluRs) play in regulating SNr functions. Immunocytochemical analysis at the light and electron microscopic levels reveal that both mGuR1a and mGluR5 are localized postsynaptically in the SNr. Consistent with this, activation of group I mGluRs depolarizes SNr GABAergic neurons. Interestingly, although both group I mGluRs (mGluR1 and mGluR5) are expressed in these neurons, the effect is mediated solely by mGluR1. Light presynaptic staining for mGluR1a and mGluR5 was also observed in some terminals forming symmetric synapses and in small unmyelinated axons. Consistent with this, activation of presynaptic mGluR1a and mGluR5 decreases inhibitory transmission in the SNr. The combination of direct excitatory effects and disinhibition induced by activation of group I mGluRs could lead to a large excitation of SNr projection neurons. This suggests that group I mGluRs are likely to play an important role in the powerful excitatory control that the STN exerts on basal ganglia output neurons.

Key words: substantia nigra pars reticulata; group I metabotropic glutamate receptors; movement disorders; slow excitatory postsynaptic potential; disinhibition; basal ganglia output nucleus
The basal ganglia are a richly interconnected group of subcortical nuclei involved in the control of motor behavior. The primary input nucleus of the basal ganglia is the striatum, and the primary output nuclei are the substantia nigra pars reticulata $(\mathrm{SNr})$ and the internal globus pallidus (entopeduncular nucleus in nonprimates). The striatum projects to these output nuclei both directly, providing an inhibitory GABAergic input, and indirectly through the external globus pallidus and the subthalamic nucleus (STN). The STN provides excitatory glutamatergic input to the SNr. A delicate balance between this inhibition and excitation is believed to be critical for motor control, and disruptions in this balance are believed to underlie a variety of movement disorders (Wichmann and DeLong, 1997, 1998)

Although much effort has been directed at elucidating the connectivity of the direct and indirect pathways, less is known about the modulatory influence various transmitters may have on these pathways. Increasing evidence suggests that G-proteincoupled metabotropic glutamate receptors (mGluRs) may play an important role in the regulation of basal ganglia functions. To date, eight mGluR subtypes (mGluR1-mGluR8) have been

\footnotetext{
Received April 30, 2001; revised June 26, 2001; accepted June 29, 2001.

This work was supported by grants from the National Institutes of Health, the National Institute of Neurological Disorders and Stroke, The National Parkinson's Foundation, the Tourette's Syndrome Association, and United States Army Medical Research and Material Command. We thank Stephanie Carter for valuable technical assistance.

M.J.M and M.W. contributed equally to this work.

Correspondence should be addressed to Dr. P. J. Conn, Merck Research Laboratories, Merck and Company Inc., 770 Sumneytown Pike, P.O. Box 4, W P46-300, West Point, PA 19486-0004. E-mail: jeff_conn@merck.com.

Copyright (ㄷ) 2001 Society for Neuroscience $\quad 0270-6474 / 01 / 217001-12 \$ 15.00 / 0$
}

cloned and are classified into three major groups based on sequence homology, coupling to second-messenger systems, and agonist selectivity (for review, see Conn and Pin, 1997). Group I mGluRs (mGluR1 and GluR5) couple to $\mathrm{G}_{\mathrm{q}}$ and phosphoinositide hydrolysis, whereas groups II (mGluR2 and mGluR3) and III (mGluR4, mGluR6, mGluR7, and mGluR8) couple to $\mathrm{G}_{\mathrm{i}} / \mathrm{G}_{\mathrm{o}}$ and related effector systems such as inhibition of adenylate cyclase. These mGluRs are widely distributed throughout the CNS in which they play important roles in regulating cell excitability and synaptic transmission.

Previous studies have shown that mGluRs are expressed throughout the basal ganglia (Testa et al., 1994, 1998; Kerner et al.,1997; Kosinski et al., 1998, 1999; Bradley et al., 1999a,b) and play important roles in the regulation of synaptic transmission in the SNr. For example, activation of presynaptic group II and III mGluRs inhibits excitatory transmission at the STN-SNr synapse (Bradley et al., 2000; Wittmann et al., 2000). One of the major postsynaptic effects of mGluRs in many brain regions is a group I mGluR-mediated slow depolarization (Crepel et al., 1994; Guerineau et al., 1994, 1995; Gereau and Conn, 1995a; Miller et al., 1995). Because glutamatergic innervation of the $\mathrm{SNr}$ from the STN plays an important role in motor control, an understanding of the roles mGluRs play in modulating SNr GABAergic neurons could provide important insight into the mechanisms involved in the regulation of SNr firing in both physiological and pathological states. We now report that activation of group I mGluRs produces an excitation of the SNr by two distinct mechanisms. Activation of postsynaptic mGluR1 induces a pronounced excitation of $\mathrm{SNr}$ GABAergic neurons that is mimicked by stimulation of excitatory afferents. In addition, activation of both mGluR1 and mGluR5 
produce a decrease in inhibitory transmission in the $\mathrm{SNr}$, resulting in increased excitability of this crucial basal ganglia output nucleus.

\section{MATERIALS AND METHODS}

$\left[R-\left(R^{*}, S^{*}\right)\right]-6-(5,6,7,8-T e t r a h y d r o-6-m e t h y l-1,3-d i o x o l o[4,5 \mathrm{gm}]$ isoquinolin5-yl)furo[3,4-e]-1,3-benzodioxol-8(6H)-one (Bicuculline), 6-cyano-7-nitroquinoxaline-2,3-dione (CNQX), $\mathrm{D}(-)$-2-amino-5-phosphonopentanoic acid (D-AP-5), $(R S)$-3,5-dihydroxyphenylglycine (DHPG), $(R S)$-3-amino2-(4-chlorophenyl)-2-hydroxypropyl-sulfonic acid (2-hydroxysaclofen), L(+)-2-amino-4-phosphonobutyric acid (L-AP-4), and ( $S)-(+)-\alpha$-amino4-carboxy-2-methylbenzeneacetic acid (LY367385) were obtained from Tocris Cookson (Ballwin, MO). (S)-(+)-2-(3'-Carboxy-bicyclo [1.1.1]pentyl-)glycine (CBPG) was obtained from Alexis Corp. (San Diego, CA). (+)-2-Aminobicyclo[3.1.0]-hexane-2,6-dicarboxylate monohydrate (LY354740) was a gift from D. Schoepp and J. Monn (Eli Lilly, Indianapolis, IN). Methylphenylethynylpyridine (MPEP) and 7-hydroxyiminocyclopropan-[b]chromen-1a-carboxylic acid ethyl ester (CPCCOEt) were gifts from R. Kuhn (Novartis, Basel, Switzerland). All other materials were obtained from Sigma (St. Louis, MO).

Antibody characterization. The specificity of antibodies used in immunocytochemical studies was tested by immunoblotting of homogenates from cell lines expressing mGluR1 or mGluR5 and a variety of brain regions. Baby hamster kidney and human embryonic kidney cell lines, respectively, expressing mGluR1 and mGluR5 were grown in highglucose DMEM with $10 \%$ FBS and $1 \%$ penicillin-streptavidin. They were washed with cold PBS, pH 7.4 and lysed in a homogenization buffer consisting of a protease inhibitor cocktail (Sigma) diluted 1:100 in $2 \mathrm{~mm}$ EDTA and 2 mM HEPES, pH 7.4. Cells were then homogenized by hand with five strokes of a Teflon pestle in a glass homogenization tube. Membranes were isolated by first centrifuging for $5 \mathrm{~min}$ at $1000 \times \mathrm{g}$. The supernatant was then spun for $30 \mathrm{~min}$ at $35,000 \times \mathrm{g}$. Finally, the membrane-rich pellets were then resuspended in $0.5 \mathrm{ml}$ of lysis buffer. For brain homogenates, adult male Sprague Dawley rats were deeply anesthetized with an intraperitoneal injection of chloral hydrate $(700$ $\mathrm{mg} / \mathrm{kg}$ ), and brains were rapidly removed and dissected on ice. Specific brain regions were homogenized, and the membranes were isolated using the same homogenization and centrifugation protocol. Protein concentration was measured using a BCA protein assay (Pierce, Rockford, IL). Equal amounts of protein were diluted 5:1 in an 6× SDS loading buffer containing $0.6 \mathrm{M}$ DL-dithiothreitol. Proteins were separated on a standard 7.5\% SDS-PAGE and transferred to Immobilon-P membranes (Millipore, Bedford, MA). Membranes were blocked for $30 \mathrm{~min}$ at $25^{\circ} \mathrm{C}$ in PBS with $3 \%$ nonfat dry milk. They were subsequently probed with primary antibody at $1: 10,000$ in blocking buffer at $4^{\circ} \mathrm{C}$ for $24 \mathrm{hr}$ with either purified mouse monoclonal $\mathrm{IgG}_{1}$ raised against the entire $\mathrm{C}$ terminus of human mGluR1a (PharMingen, San Diego, CA) or purified rabbit polyclonal $\mathrm{IgG}_{1}$ raised against the mGluR5 $\mathrm{C}$ terminus (KSSPKYDTLIIRDYTNSSSSL; Upstate Biotechnologies, Lake Placid, NY). Membranes were next washed in PBS twice for 10 min, incubated with an HRP-conjugated secondary antibody: goat anti-mouse for mGluR1 and goat anti-rabbit for mGluR5. Both secondary antibodies were diluted 1:10,000 in blocking buffer and incubated for $1 \mathrm{hr}$ at $25^{\circ} \mathrm{C}$. Blots were then washed once for $5 \mathrm{~min}$ in TBS with $3 \%$ nonfat dry milk, twice for $5 \mathrm{~min}$ in TBS with $0.1 \%$ Tween 20 , once for $5 \mathrm{~min}$ in TBS, and developed using the ECL chemiluminescent kit (Amersham Pharmacia Biotech, Buckinghamshire, UK).

Immunocytochemistry. Two male Sprague Dawley rats were deeply anesthetized with ketamine $(100 \mathrm{mg} / \mathrm{kg})$ and dormitor $(10 \mathrm{mg} / \mathrm{kg})$ and transcardially perfused with cold, oxygenated Ringer's solution followed by $500 \mathrm{ml}$ of $4 \%$ paraformaldehyde and $0.1 \%$ glutaraldehyde in phosphate buffer (PB) (0.1 M, pH 7.4) and $300 \mathrm{ml}$ of cold PB. Next, the brain was removed from the skull and stored in PBS $(0.01 \mathrm{M}, \mathrm{pH} 7.4)$ before being sliced on a vibrating microtome into $60 \mu \mathrm{M}$ transverse sections. These sections were then treated with $1.0 \%$ sodium borohydride for 20 min and rinsed in PBS.

The sections were preincubated at room temperature in a solution containing $10 \%$ normal goat serum (NGS), $1.0 \%$ bovine serum albumin (BSA), and $0.3 \%$ Triton X-100 in PBS for $1 \mathrm{hr}$. They were then incubated overnight at room temperature in a solution containing primary antibodies raised against synthetic peptides corresponding to the $\mathrm{C}$ terminus of either mGluR1a [PharMingen and Chemicon (Temecula, CA)] or mGluR5 (Upstate Biotechnologies) diluted at $0.5-1.0 \mathrm{mg} / \mathrm{ml}$ in a solution containing $1.0 \%$ NGS, $1.0 \%$ BSA, and $0.3 \%$ Triton X-100 in PBS. Next, the sections were rinsed in PBS and transferred for $90 \mathrm{~min}$ at room temperature to a secondary antibody solution containing biotinylated goat-anti-rabbit IgGs (Vector Laboratories, Burlingame, CA) diluted 1:200 in the primary antibody diluent solution. After rinsing, sections were put in a solution containing 1:100 avidin-biotin-peroxidase complex (ABC; Vector Laboratories) for $90 \mathrm{~min}$. The tissue was then washed in PBS and $0.05 \mathrm{M}$ Tris buffer before being transferred to a solution containing $0.01 \mathrm{M}$ imidazole, $0.0005 \%$ hydrogen peroxide, and $0.025 \%$ 3,3-diaminobenzidine tetrahydrochloride (DAB) (Sigma) in Tris for 7-10 min. Sections were then mounted on gelatin-coated slides, dried, and coverslipped with Permount.

For electron microscope studies, the sections were treated with cryoprotectant for $20 \mathrm{~min}$ and transferred to a $-80^{\circ} \mathrm{C}$ freezer for an additional $20 \mathrm{~min}$. They were then thawed and treated with successively decreasing concentrations of cryoprotectant and finally PBS. The immunocytochemical procedure was the same as used for the light microscope, except that Triton X-100 was not used, and the incubation in the primary antibody was performed at $4^{\circ} \mathrm{C}$ for $48 \mathrm{hr}$.

After DAB revelation, the sections were processed for the electron microscope. They were first washed in $0.1 \mathrm{M}$ PB for $30 \mathrm{~min}$ and then post-fixed in $1.0 \%$ osmium tetroxide for $10 \mathrm{~min}$. After rinsing in $\mathrm{PB}$, the tissue was dehydrated by a series of increasing concentrations of ethanol $(50,70,90$, and $100 \%)$. Uranyl acetate $(1.0 \%)$ was added to the $70 \%$ ethanol to enhance contrast in the tissue. Next, the sections were exposed to propylene oxide and embedded in epoxy resin (Durcupan; Fluka, Buchs, Switzerland) for $12 \mathrm{hr}$. They were then mounted on slides, coverslipped, and heated at $60^{\circ} \mathrm{C}$ for $48 \mathrm{hr}$.

Four blocks (two for mGluR1a and two for mGluR5) were cut from the $\mathrm{SNr}$ and mounted on resin carriers to allow for the collection of ultrathin sections using an ultramicrotome (Ultracut T2; Leica, Nussloch, Germany). The ultrathin sections were collected on single-slot copper grids, stained with lead citrate for $5 \mathrm{~min}$ to enhance contrast, and examined on a Zeiss (Thornwood, NY) EM-10C electron microscope.

Electron micrographs were taken at $10,000-31,500 \times$ magnification to characterize the nature of immunoreactive elements in the SNr.

Electrophysiology. Whole-cell patch-clamp recordings were obtained as described previously (Marino et al., 1998; Bradley et al., 2000). Fifteento 18 -d-old Sprague Dawley rats were used for all patch-clamp studies. After decapitation, brains were rapidly removed and submerged in an ice-cold sucrose buffer [in mM: 187 sucrose, $3 \mathrm{KCl}, 1.9 \mathrm{MgSO}_{4}, 1.2$ $\mathrm{KH}_{2} \mathrm{PO}_{4}, 20$ glucose, and $26 \mathrm{NaHCO}_{3}$ (equilibrated with $95 \% \mathrm{O}_{2}-5 \%$ $\left.\mathrm{CO}_{2}\right)$ ]. Parasagittal or horizontal slices (300 $\mu \mathrm{m}$ thick) were made using a Vibraslicer (World Precision Instruments, Sarasota, FL). Slices were transferred to a holding chamber containing normal artificial CSF (ACSF) [in mM: $124 \mathrm{NaCl}, 2.5 \mathrm{KCl}, 1.3 \mathrm{MgSO}_{4}, 1.0 \mathrm{NaH}_{2} \mathrm{PO}_{4}, 2.0$ $\mathrm{CaCl}_{2}, 20$ glucose, $26 \mathrm{NaHCO}_{3}$ (equilibrated with $95 \% \mathrm{O}_{2}-5 \% \mathrm{CO}_{2}$ )]. In some experiments, $5 \mu \mathrm{M}$ glutathione, $500 \mu \mathrm{M}$ pyruvate, and $250 \mu \mathrm{M}$ kynurenate were included in the sucrose buffer and holding chamber. These additional compounds tended to increase slice viability but did not have any effect on experimental outcome. Therefore, data from these two groups have been pooled. Slices were transferred to the stage of a Hoffman modulation contrast microscope and continuously perfused with room temperature $\operatorname{ACSF}\left(\sim 3 \mathrm{ml} / \mathrm{min}, 23-24^{\circ} \mathrm{C}\right)$. Neurons in the substantia nigra pars reticulata were visualized with a $40 \times$ water immersion lens. Patch electrodes were pulled from borosilicate glass on a Narashige (Tokyo, Japan) vertical patch pipette puller and filled with the following (in mM): 140 potassium gluconate, $10 \mathrm{HEPES}, 10 \mathrm{NaCl}, 0.6$ EGTA, 0.2 GTP, and 2 ATP (pH adjusted to 7.5 with $0.5 \mathrm{~N} \mathrm{NaOH}$ ). Biocytin (0.5\%, free base) was added just before use. Electrode resistance was 3-7 M $\Omega$. For blockade of potassium channels, a modified ACSF was used (in mM: $108 \mathrm{NaCl}, 19.6 \mathrm{NaC}_{2} \mathrm{H}_{3} \mathrm{O}_{2}, 6 \mathrm{MgCl}_{2}, 0.1 \mathrm{CaCl}_{2}$, $2.0 \mathrm{BaCl}_{2}, 6.0 \mathrm{CsCl}_{2}, 20$ glucose, $26 \mathrm{NaHCO}_{3}, 3$ 4-aminopyridine, and 25 tetraethylammonium chloride), and the intracellular solution was modified replacing the potassium gluconate with cesium methanesolfonate. For measurement of synaptically evoked slow EPSPs, ACSF was warmed to $34^{\circ} \mathrm{C}$. Patch electrodes were filled with (in mM): 115 potassium methylsulfate, 5 HEPES, $20 \mathrm{NaCl}, 1.5 \mathrm{MgCl}_{2}, 0.1$ EGTA, $2 \mathrm{Mg}$-ATP, 0.5 Na-GTP, and 10 phosphocretine ( $\mathrm{pH}$ adjusted to 7.5 with $0.5 \mathrm{M} \mathrm{KOH}$ ). Bipolar tungsten electrodes were used to apply stimuli to the $\mathrm{SNr} \sim 100$ $\mu \mathrm{m}$ rostral to the recording site. Slow EPSPs were evoked in the presence of blockers of AMPA (10 $\mu \mathrm{M}$ CNQX), NMDA (10 $\mu \mathrm{M}$ D-AP-5), GABA (50 $\mu \mathrm{M}$ picrotoxin), $\mathrm{GABA}_{\mathrm{B}}(200 \mu \mathrm{M}$ 2-hydroxysaclofen $)$, dopamine (10 $\mu \mathrm{M}$ haloperidol), and glycine (10 $\mu \mathrm{M}$ strychnine) receptors. The stimulation parameters were $2-14 \mu \mathrm{A}, 200 \mu \mathrm{sec}$, delivered in a train of $100-200 \mathrm{msec}$ duration at a rate of $25-100 \mathrm{~Hz}$. IPSCs were evoked with 
A

\section{$\underline{\text { Anti mGluR1a }}$}

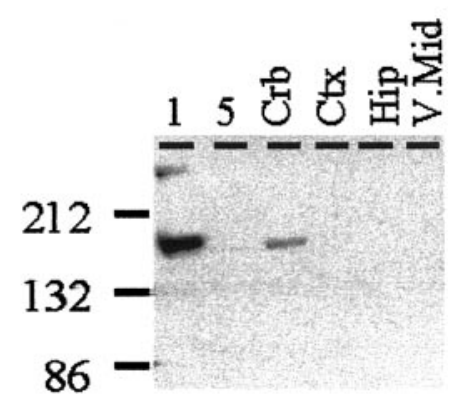

B

\section{$\underline{\text { Anti mGluR5 }}$}

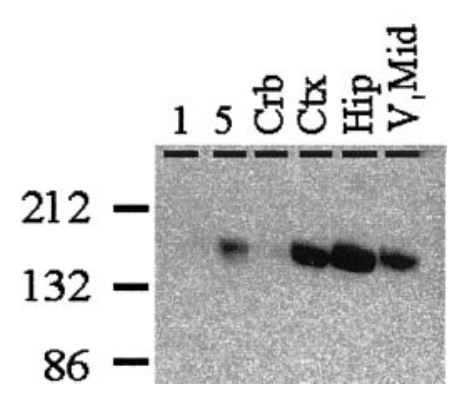

Figure 1. The specificity of antibodies used for immunocytochemistry. Protein from cell lines expressing mGluR1a or mGluR5 or from homogenates of rat cerebellum $(\mathrm{Crb})$, cortex $(\mathrm{Ctx})$, hippocampus (Hip), and ventral midbrain $(V$. Mid) were separated by SDS-PAGE and transferred to membranes. The resulting blots were probed with either the monoclonal anti-mGluR1a $(A)$ or anti-mGluR5 $(B)$ antibodies as described in Materials and Methods. Each antibody specifically labels a band from the appropriate cell line and exhibits a distribution consistent with the known expression of the group I mGluRs. Similar results were observed with the polyclonal anti-mGluR1a antibody.

the stimulation electrode placed within the $\mathrm{SNr}$ rostrally or caudally to the recorded cell and recorded at a holding potential of $-50 \mathrm{mV}$. CNQX $(10-20 \mu \mathrm{M})$ and $10-20 \mu \mathrm{M}$ D-AP-5 were continuously added to the bath to block excitatory transmission. To study miniature IPSCs (mIPSCs), the $140 \mathrm{~mm}$ potassium gluconate in the internal solution were substituted with $140 \mathrm{~mm} \mathrm{CsCl}$ to reduce postsynaptic mGluR effects and increase currents. Therefore, inward mIPSCs were recorded at a holding potential of $-80 \mathrm{mV}$ in the presence $1 \mu \mathrm{M}$ tetrodotoxin (TTX).

Data analysis. All curve fitting was performed using the MarquardtLevenburg algorithm as implemented in the SigmaPlot software package (SPSS, Chicago, IL). To determine an accurate reversal potential from the $I-V$ ramps presented in Figure 6, the current-voltage relationships were fit with an arbitrary higher-order polynomial function of the form $I=I_{0}+\left(C_{1} V\right)+\left(C_{2} V^{2}\right) \ldots+\left(C_{\mathrm{i}} V^{\mathrm{i}}\right)$, where $I$ is the whole-cell current, $V$ is the command potential, $I_{0}$ is an offset variable, and $C_{\mathrm{i}}$ are constants. It was found that a third- order polynomial $(i=3)$ provided the best fit, with additional terms decreasing the error about the fit by $<1 \%$. Concentration-response curves were fit with a three-parameter Hill equation to obtain $\mathrm{EC}_{50}$ and Hill slope values. All values are reported as mean \pm SEM.

\section{RESULTS}

\section{Antibody specificity}

To assess the specificity of the antibodies used in these studies, we performed immunoblot analysis on proteins isolated from cell lines and specific rat brain regions. As shown in Figure $1 A$, the anti mGluR1 monoclonal antibody (PharMingen) specifically labels a band at $\sim 140 \mathrm{kDa}$ in lanes containing protein from cells expressing mGluR1 but not from cells expressing mGluR5. In addition, the mGluR1 antibody specifically labels a similar band in cerebellar homogenate, demonstrating a distribution consistent with previous reports (Martin et al., 1992; Shigemoto et al., 1992; Petralia et al., 1997). Similar results were observed with both mGluR1-selective antibodies used in these studies. In contrast to this, anti-mGluR5 polyclonal antibody specifically labels a similar band from cells expressing mGluR5 and, consistent with the known distribution of mGluR5, exhibits a broader labeling of brain homogenates in noncerebellar regions (Shigemoto et al., 1993; Romano et al., 1995) (Fig. 1B). In addition to these immunoblot studies, we also observed light level immunostaining for each antibody, consistent with previously reported distributions (data not shown).

\section{Localization of group I mGluRs in the SNr}

Previous studies have demonstrated the expression of both mGluR1 and mGluR5 in the SNr (Testa et al., 1994, 1998). However, these studies did not address the subcellular and subsynaptic localization of these receptors. To determine whether group I mGluRs are postsynaptically localized in the $\mathrm{SNr}$, we performed immunocytochemical studies with antibodies selective for mGluR1a and mGluR5.

At the light microscopic level, the $\mathrm{SNr}$ exhibited labeling for both mGluR1a (Fig. 2A,B) and mGluR5 (Fig. 3A, $B$ ). To determine whether this immunoreactivity represents presynaptic or postsynaptic staining, we performed immunocytochemical analyses at the electron microscope level. Both antibodies primarily labeled dendritic processes that formed symmetric and asymmetric synapses with unlabeled terminals (Figs. 2,3). Although the majority of labeling was postsynaptic, immunoreactivity for both group I mGluRs was also found in small unmyelinated axons and a few axon terminals (Figs. $2 C, 3 C$ ). In the case of presynaptic labeling for both group I mGluRs, the immunoreactivity was seen only in terminals forming symmetric synapses. A few glial processes were also labeled with both antibodies. Most immunoreactive dendrites were tightly surrounded by a large density of striatal-like terminals forming symmetric synapses (Figs. 2C,D; $3 C-E$ ), an ultrastructural feature typical of SNr GABAergic neurons (Smith and Bolam, 1991). In contrast, SNc dopaminergic neurons are much less innervated (Bolam and Smith, 1990). These data suggest that the majority of immunoreactive elements labeled with the two group I mGluR antibodies belong to $\mathrm{SNr}$ GABAergic neurons. Immunoreactive elements were counted in a random sample of $\mathrm{SNr}$ tissue to determine the relative frequency of group I mGluR-immunopositive elements. The relative distribution of mGluR1a immunoreactivity, expressed as a percentage of total labeled elements, was $64.2 \%$ dendrites, $34.3 \%$ axons, $0.4 \%$ somata, $0.8 \%$ terminals, and $0.4 \%$ glia. The relative distribution of mGluR5 immunoreactivity was $58.7 \%$ dendrites, $40.2 \%$ axons, $0.5 \%$ somata, and no observed labeling in terminals or glia.

\section{Electrophysiological identification of GABAergic neurons in the SNr}

For electrophysiological analysis of the roles of mGluRs in $\mathrm{SNr}$ GABAergic projection neurons, it is critical to differentiate between GABAergic neurons and the smaller population of dopaminergic neurons in this region. Fortunately, these two neuronal types exhibit distinct electrophysiological and morphological features. Therefore, we used electrophysiological criteria that were established previously to distinguish between dopaminergic neurons and GABAergic projection neurons (Nakanishi et al., 1987; 

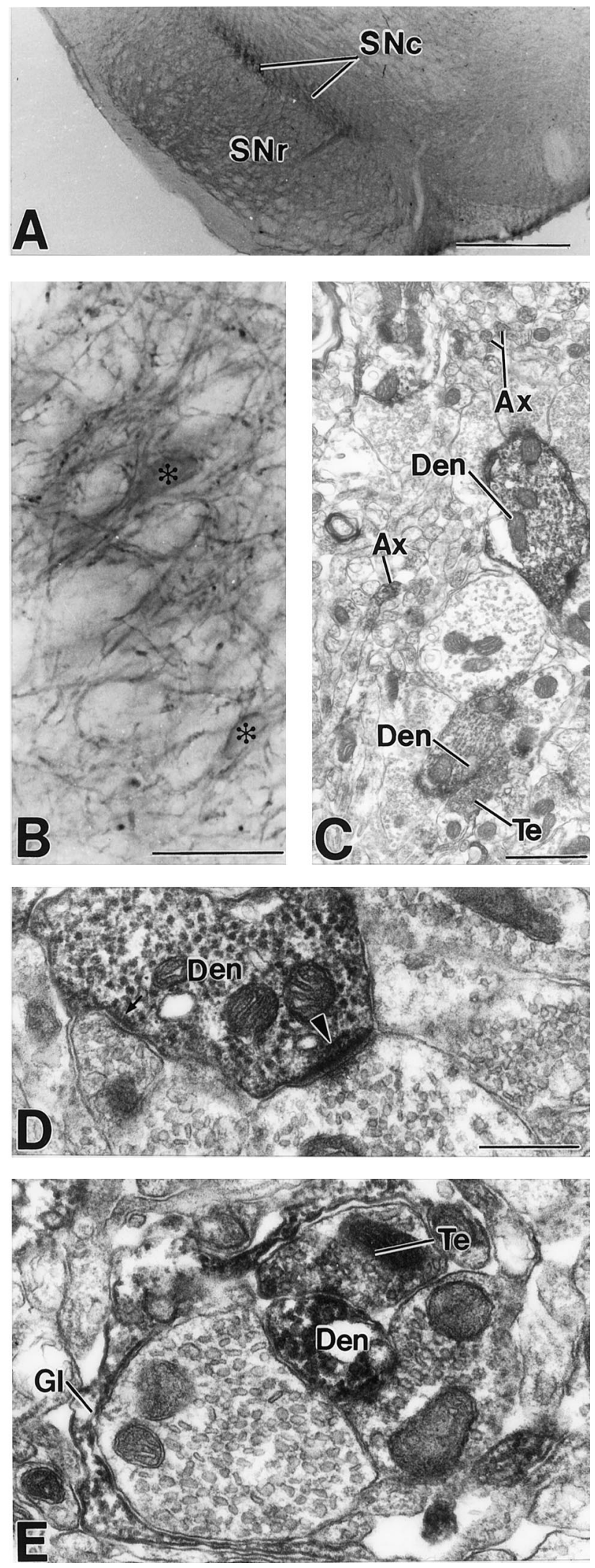

Figure 2. mGluR1a immunoreactivity in the SNr. $A$, Low-power light micrograph of mGluR1a immunostaining in the SNc and SNr. B, Highpower light micrograph of mGluR1a-immunoreactive processes in the SNr. Lightly labeled neuronal cell bodies are indicated by asterisks. $C$, Low-power electron micrograph of mGluR1a-immunoreactive dendrites
Hausser et al., 1995; Richards et al., 1997). GABAergic neurons exhibit a high rate of spontaneous repetitive firing, short-duration action potentials (half-amplitude duration, $1.7 \pm 0.2 \mathrm{msec} ; n=4$ ), little spike accommodation, and a lack of inward rectification (Fig. 4). In contrast, dopaminergic neurons display no or low-frequency spontaneous firing, longer-duration action potentials (halfamplitude duration, $7.0 \pm 0.5 \mathrm{msec}$; $n=4$ ), strong spike accommodation, and a pronounced inward rectification (Fig. 4). Light microscopic examination of biocytin-filled neurons indicated that GABAergic neurons had extensive dendritic arborizations close to the cell body, whereas dopaminergic neurons had sparser dendritic structure (data not shown). All data presented in this study are from electrophysiologically identified GABAergic neurons.

\section{Activation of group I mGluRs depolarizes SNr GABAergic neurons}

Previous studies have demonstrated that all three groups of mGluRs are expressed in the SNr (Testa et al., 1994, 1998). We therefore used maximal concentrations of group-selective mGluR agonists to determine whether activation of these receptors has an effect on membrane properties of SNr GABAergic neurons. In the presence of $0.5 \mu \mathrm{M}$ TTX, application of the group I mGluRselective agonist DHPG induces a robust direct depolarization (300 $\mu \mathrm{M}$ DHPG, $16.1 \pm 2.6 \mathrm{mV} ; n=5$ ) of SNr neurons that reverses during drug washout (Fig. $5 A, C$ ). This depolarization is accompanied by a significant increase in input resistance (predrug, $498 \pm 70 \mathrm{M} \Omega, n=4 ; 100 \mu \mathrm{M}$ DHPG, $619 \pm 89 \mathrm{M} \Omega, n=4$; $p<0.05$; paired $t$ test) (Fig. $5 B$ ), suggesting that a DHPGinduced decrease in membrane conductance underlies this effect. The concentration-response relationship for DHPG-induced depolarization of SNr GABAergic neurons exhibited a steep sigmoid shape and was fit with a Hill equation that gave an $\mathrm{EC}_{50}$ of $37 \mu \mathrm{M}$ and a Hill slope of 2.6 (Fig. 5D), consistent with an effect on group I mGluRs (Schoepp et al., 1994; Gereau and Conn, 1995a). In contrast to this group I mGluR-mediated depolarization, the group II-selective agonist LY354740 (Monn et al., 1997; Kingston et al., 1998) and the group III-selective agonist L-AP-4 (Conn and Pin, 1997) had no significant effect on resting membrane potential (Fig. $5 A-C$ ). Therefore, we focused on the physiology and pharmacology of the group I mGluR-mediated depolarization.

To determine the effect of group I mGluR activation on action potential firing in SNr GABAergic neurons, we applied the selective group I mGluR agonist DHPG in the absence of TTX. At the beginning of whole-cell recording, cells fire spontaneous action potentials (Fig. 4); however, within a few minutes, cells tend to hyperpolarize and do not fire spontaneously. Application of $100 \mu \mathrm{M}$ DHPG induced a robust depolarization and a large increase in action potential firing (Fig. 5E). This DHPG-induced firing is completely blocked by injection of hyperpolarizing current to maintain a $-65 \mathrm{mV}$ membrane potential during drug

\section{$\leftarrow$}

(Den) in SNr. Note that the immunoreactivity is mostly found in dendritic processes but also occurs in small, unmyelinated axons $(A x)$ and a few axon terminals $(T e)$. $D$, High-power electron micrograph of mGluR1aimmunoreactive dendrites that form asymmetric (arrowhead) and symmetric (arrow) synapses with unlabeled terminals. E, High-power electron micrograph showing an mGluR1a-immunoreactive terminal in contact with a small, labeled dendrite. Note also the presence of an immunoreactive glial process $(G l)$ surrounding an unlabeled terminal. Scale bars: $A$, $500 \mu \mathrm{m} ; B, 50 \mu \mathrm{m} ; C, 1 \mu \mathrm{m} ; D, E, 0.5 \mu \mathrm{m}$. 

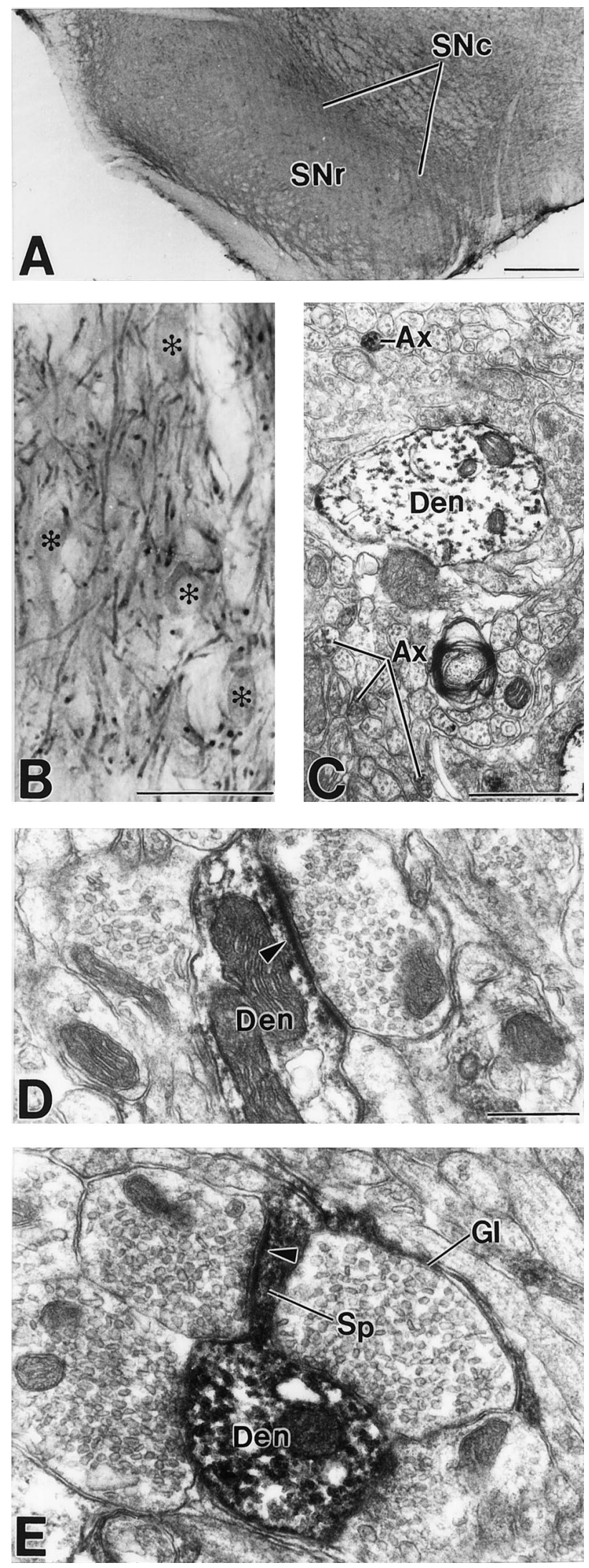

Figure 3. mGluR5-immunoreactive subtype within the SNr. A, Lowpower light micrograph of mGluR5 immunostaining in the $\mathrm{SNc}$ and $\mathrm{SNr}$. $B$, High-power light micrograph of mGluR5-immunoreactive processes in the SNr. Labeled cell bodies are indicated by asterisks. $C$, Low-power electron micrographs of mGluR5-immunoreactive elements in the SNr.
A
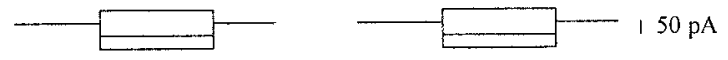

B
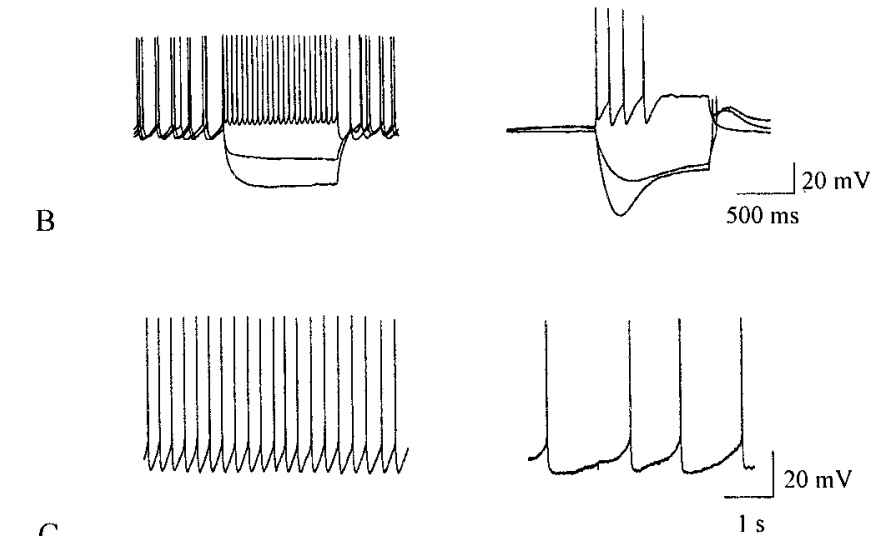

$\mathrm{C}$
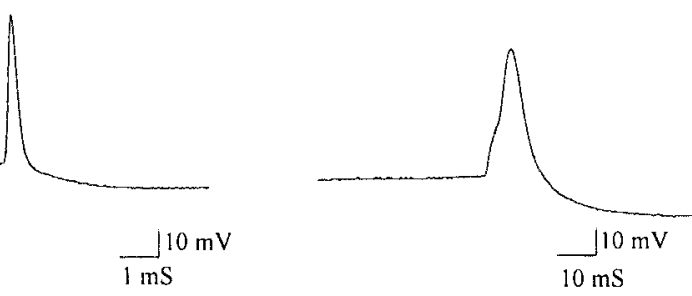

Figure 4. Demonstration of the identification of SNr GABAergic neurons. A, Response of a GABAergic (left) and dopaminergic (right) neuron to depolarizing and hyperpolarizing current injections. Note the pronounced spike frequency adaptation and inward rectification exhibited by the dopaminergic cell that is absent in the GABAergic cell. $B$, Examples of spike activity from resting cells. GABAergic neurons (left) fire at high frequency, whereas dopaminergic neurons (right) exhibit lower frequency or no spontaneous activity. $C$, Comparison of single action potentials from a GABAergic (left) and dopaminergic (right) neuron. All data presented here are from electrophysiologically identified GABAergic neurons.

application and is mimicked by direct depolarization of the cells to the same membrane potential $(100 \mu \mathrm{M}$ DHPG, $3.8 \pm 0.3 \mathrm{~Hz}$, $n=4$; direct depolarization $3.2 \pm 0.7 \mathrm{~Hz}, n=4 ; p>0.05$; Student's $t$ test). These data suggest that the increase in firing is solely attributable to the depolarization and that mGluR activation does not have other effects on membrane properties of $\mathrm{SNr}$ neurons to increase firing frequency.

In other neurons, activation of group I mGluRs has been demonstrated to depolarize the cells by inhibition of a leak potassium conductance (Guerineau et al., 1994) or by an increase in a nonselective cationic conductance (Guerineau et al., 1995; Miller et al., 1995). Our observation that DHPG causes an increase in input resistance suggests that inhibition of leak potassium conductance is the most likely mechanism underlying this effect. Consistent with this, voltage-clamp analysis revealed a DHPG-induced inward current underlying the depolarization (Fig. 6A). Voltage ramps between -40 and $-120 \mathrm{mV}(20 \mathrm{mV} / \mathrm{sec})$ were used to establish a current-voltage relationship of the

Note that the mGluR5 immunoreactivity is present in axonal $(A x)$ and dendritic process. $D, E$, High-power electron micrographs of mGluR5immunoreactive dendrites (Den) and spines $(S p)$ that form asymmetric synapses (arrowheads) with unlabeled terminals. Note the presence of an immunoreactive glial process $(G l)$. Scale bars: $A, 500 \mu \mathrm{m} ; B, 50 \mu \mathrm{m} ; C, 1$ $\mu \mathrm{m} ; D, E, 0.5 \mu \mathrm{m}$. 
A
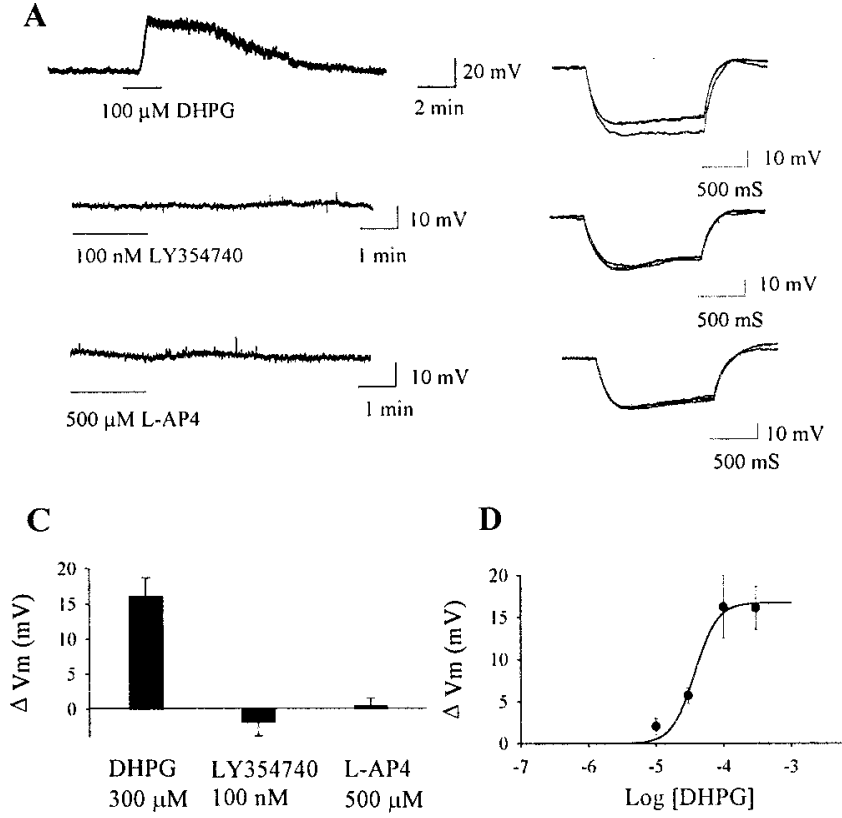

D

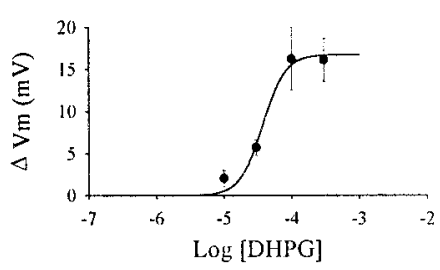

$\mathbf{E}$

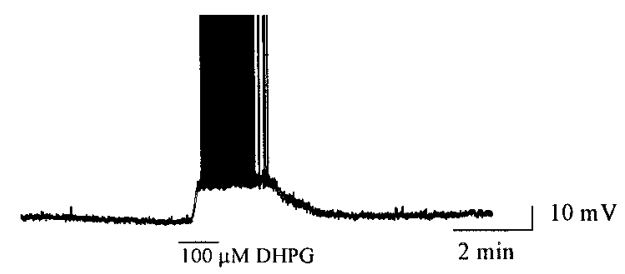

Figure 5. DHPG induces a group I mGluR-mediated depolarization of SNr neurons. DHPG $(100 \mu \mathrm{M})$ induces a depolarization $(A)$ and concomitant increase in input resistance in SNr GABAergic neurons $(B)$. Maximal concentrations of the group II-selective agonist LY354740 and the group III-selective agonist L-AP-4 are without effect. $C$, Mean \pm SEM of data from five cells demonstrating that, at maximal concentrations, only the group I agonist DHPG induces a depolarization. $D$, Concentrationresponse relationship of the DHPG-induced depolarization. $E$, The effect of DHPG applied in the absence of TTX to demonstrate the robust increase in firing produced by activation of group I mGluRs.

DHPG-induced current. Application of $100 \mu \mathrm{M}$ DHPG induced a change in the slope of the whole-cell current-voltage relationship (Fig. 6B). Subtracting the trace in the presence of DHPG from the predrug $I-V$ trace reveals the $I-V$ relationship for the DHPGinduced current. This current was best fit with a third-order polynomial function (see Materials and Methods) (Fig. 6C). The interpolated reversal potential of $-111.7 \pm 7.4 \mathrm{mV}(n=5)$ is in good agreement with the calculated Nernst equilibrium potential for potassium $(-103.4 \mathrm{mV})$. In experiments in which cesium was included in both the intracellular and extracellular solutions and the ACSF included 4-aminopyridine and tetraethylammonium to block potassium channels, the DHPG-induced current was eliminated (Fig. 6C,D). Together, these data suggest that the DHPGinduced depolarization of SNr GABAergic neurons is mediated by decreasing a leak potassium conductance.

\section{The DHPG-induced excitation of SNr GABAergic neurons is mediated by mGluR1}

Our findings that both mGluR1a and mGluR5 are postsynaptically localized in $\mathrm{SNr}$ projection neurons suggests that both of these receptors could be involved in the DHPG-induced depo-
A

B
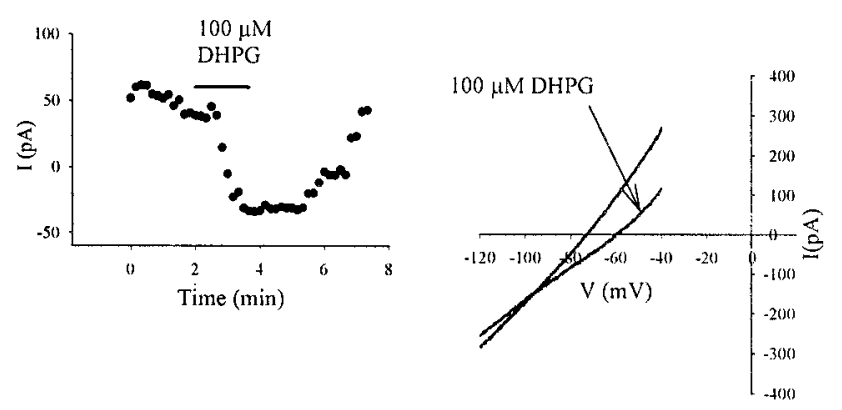

C

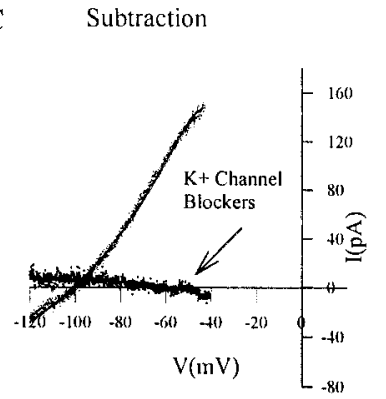

D

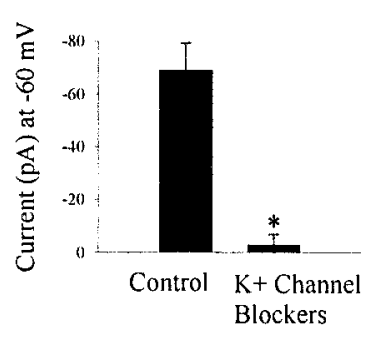

Figure 6. Analysis of mGluR-mediated current in SNr GABAergic neurons. $A$, Application of $100 \mu \mathrm{M}$ DHPG induces an inward shift in holding current that reverses on drug washout. $B$, This inward shift is evident in the whole-cell current-voltage relationship determined by applying voltage ramps from -40 to $-120 \mathrm{mV}$. $C$, Subtracting the trace in the presence of DHPG from the predrug $I-V$ trace reveals an $I-V$ relationship that reverses near the predicted potassium equilibrium potential. The solid line underlying the trace indicates the third-order polynomial fit described in Materials and Methods. Note that the inclusion of blockers of potassium channels inhibits this current. $D$, Mean \pm SEM of data from four cells in each condition comparing the DHPG-induced current recorded at a holding potential of $-60 \mathrm{mV}$ in control cells and in the presence of potassium channel blockers. ${ }^{*} p<0.01 ; t$ test.

larization. To determine the role each of these receptors plays in this effect, we used newly available pharmacological tools that distinguish between mGluR1 and mGluR5. CBPG, a partial agonist at mGluR5 that has antagonistic properties at mGluR1 (Mannaioni et al., 1999) failed to induce a depolarization at maximal concentrations (Fig. $7 A, B$ ), indicating that the depolarizing effect of DHPG is likely attributable to activation of mGluR1. Consistent with this, pretreatment with the highly selective, noncompetitive mGluR1 antagonist CPCCOEt (Annoura et al., 1996; Casabona et al., 1997; Litschig et al., 1999) or the highly selective, competitive mGluR1 antagonist LY367385 (Clark et al., 1997) produced a significant reduction in the DHPG-induced depolarization of SNr GABAergic neurons (Fig. $7 A, B)$. Pretreatment with MPEP, a highly selective noncompetitive antagonist of mGluR5, had no significant effect at concentrations shown to be effective at blocking mGluR5 in other systems (Bowes et al., 1999; Gasparini et al., 1999) (Fig. 7A,B).

\section{mGluR1 mediates a slow EPSP in SNr GABAergic neurons}

The data presented thus far indicate that mGluR1 mediates direct excitation of $\mathrm{SNr}$ projection neurons. The $\mathrm{SNr}$ receives a sparse yet important glutamatergic innervation from the STN, and burst firing of the STN is known to play a key role in several neurological disorders, including Parkinson's disease (PD) (Hollerman and Grace, 1992; Bergman et al., 1994; Hassani et al., 1996). If 
A
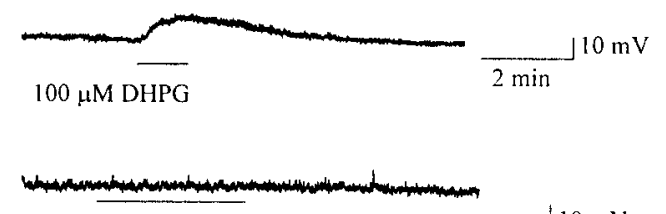

$100 \mu \mathrm{M}$ CBPG

$$
\frac{1 \mathrm{~min}}{10 \mathrm{mV}}
$$

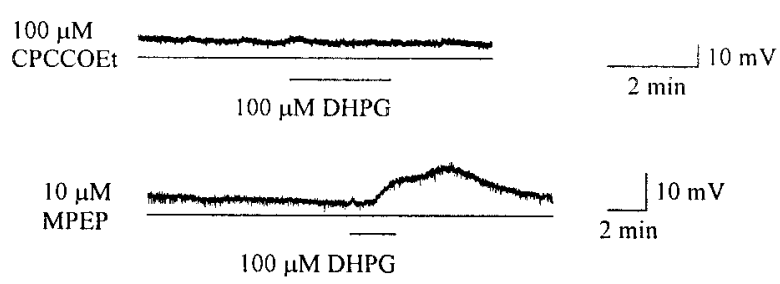

B

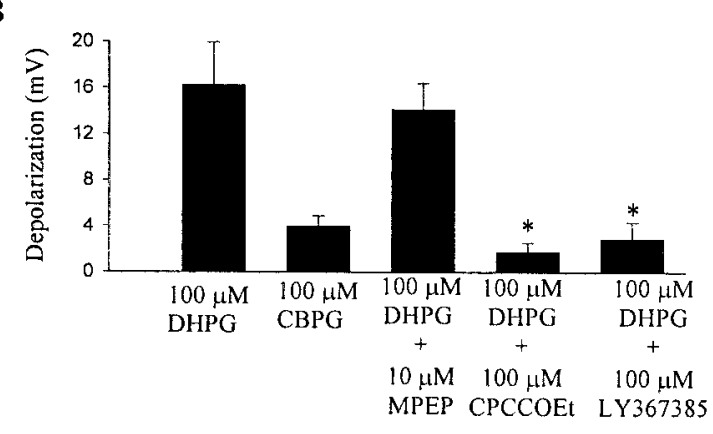

Figure 7. The group I mGluR-induced depolarization is mediated by mGluR1. $A$, Representative traces demonstrating that the DHPGinduced depolarization of SNr GABAergic neurons is not mimicked by the mGluR5-selective agonist CBPG. Furthermore, preincubation with the highly selective noncompetitive mGluR1 antagonist CPCCOEt or the highly selective competitive mGluR1 antagonist LY367385 fully blocks the DHPG-induced depolarization, whereas the mGluR5-selective antagonist MPEP is without effect. $B$, Mean \pm SEM of data from five cells per condition demonstrating the selective antagonism of the group I mGluRmediated depolarization of $\mathrm{SNr}$ projection neurons by the mGluR1selective antagonists. ${ }^{*} p<0.01$; Student's $t$ test.

activation of glutamatergic afferents to the $\mathrm{SNr}$ release sufficient glutamate to activate mGluR1, the resulting excitation of $\mathrm{SNr}$ projection neurons could play an important role in these disease states. We tested this hypothesis by recording from $\mathrm{SNr}$ GABAergic neurons in the presence of ionotropic glutamate receptor and GABA receptor antagonists, as well as haloperidol to block dopamine receptors and strychnine to block glycine receptors. High-frequency stimulation of the afferents within the $\mathrm{SNr}$ produced a robust and reliable slow EPSP that reached threshold for action potential firing (Fig. 8A). Recent reports have demonstrated that, under carefully controlled conditions, synaptically released glutamate acting on group I mGluRs can induce a hyperpolarizing response in midbrain dopamine neurons (Fiorillo and Williams, 1998). Under the conditions used in these studies, we were able to elicit a hyperpolarizing response in four of four dopaminergic neurons recorded from the $\mathrm{SNc}-$ ventral tegmental area (Fig. $8 A$ ). However, we never observed a hyperpolarizing response in $\mathrm{SNr}$ neurons (0 of 22 cells). This suggests that depolarization is the primary action of glutamate acting on group I mGluRs on SNr GABAergic neurons. Consistent with mediation by mGluR1, this slow EPSP was reversibly blocked by $300 \mu \mathrm{M}$ LY367385 (predrug, $9.0 \pm 1.2 \mathrm{mV}$; LY367385, $3.9 \pm 0.7 \mathrm{mV} ; n=6 ; p<0.05$; paired $t$ test) (Fig. $8 B, C)$, whereas
A

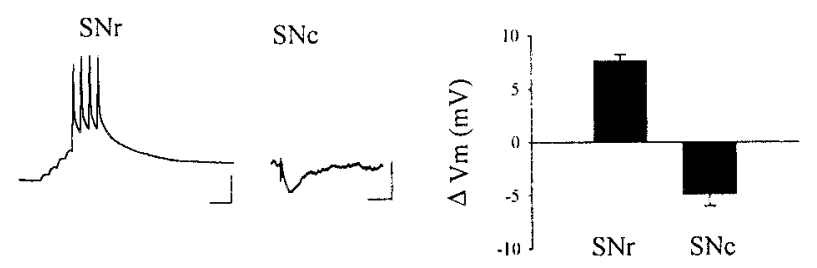

B

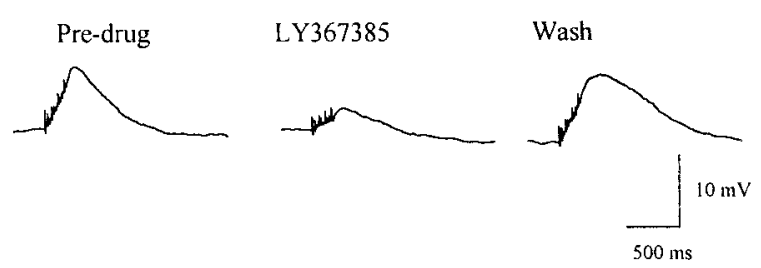

C

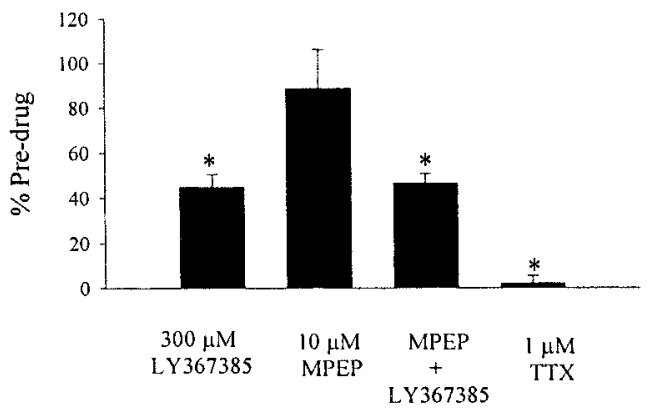

Figure 8. mGluR1 mediates a slow EPSP in SNr GABAergic neurons. $A$, High-frequency stimulation of afferents in the SNr elicits a slow EPSP that exceeds action potential threshold and induces firing. Similar experiments in dopaminergic neurons of the SNc reveal a hyperpolarizing response; however, the only response observed in SNr GABAergic neurons is a depolarization. Representative traces $(B)$ and mean \pm SEM data $(C)$ demonstrating the inhibition of the slow EPSP by the mGluR1-selective antagonist LY367385. MPEP alone or in the presence of LY367385 is without effect. $* p<0.05 ; t$ test. This slow EPSP is fully blocked by $1 \mu \mathrm{M}$ TTX, suggesting that the residual slow EPSP in the presence of LY367385 is mediated by the release of some transmitter acting on a receptor other than a group I mGluR. Calibration in $A$ has the same value as in $B$. Membrane potential in $A$ was $-50 \mathrm{mV}$. For experiments in $B$ and $C$, membrane potential was manually held at $-70 \mathrm{mV}$ by current injection to avoid spiking and allow for accurate quantification.

the mGluR5-selective antagonist MPEP was without significant effect (predrug, $7.8 \pm 1.0 \mathrm{mV}$; MPEP, $6.4 \pm 0.9 \mathrm{mV} ; n=6 ; p>$ 0.05 ; paired $t$ test). Because it is possible that a small component of the slow EPSP is mediated by mGluR5, which is not detectable in the presence of the larger mGluR1-mediated component, we applied a combination of the two selective antagonist. This combination did not produce any inhibition greater than that observed with LY367385 alone (inhibition by LY367385, $44.8 \pm$ $5.6 \%, n=6$; inhibition by LY367385 plus MPEP, $46.5 \pm 4.2 \%$, $n=4 ; p>0.05 ; t$ test) (Fig. 8C). Interestingly, application of $1 \mu \mathrm{M}$ tetrodotoxin fully blocked the slow EPSP (predrug, $8.0 \pm 1.0 \mathrm{mV}$; TTX, $0.1 \pm 0.3 \mathrm{mV} ; n=3 ; p<0.05$; paired $t$ test), suggesting that the LY367385-insensitive component of the slow EPSP is mediated by the action potential-dependent release of neurotransmitter acting on a receptor other than the group I mGluRs.

\section{Group I mGluRs decrease inhibitory transmission in the SNr}

It was surprising that our immunocytochemical studies revealed presynaptic labeling in the SNr. In some other brain regions, mGluRs can act as heteroreceptors to reduce GABA release and 
A

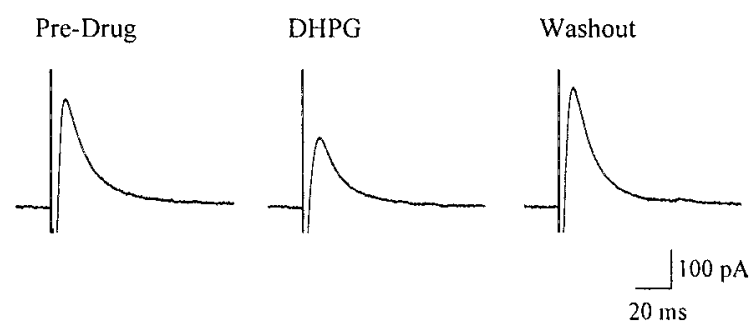

B

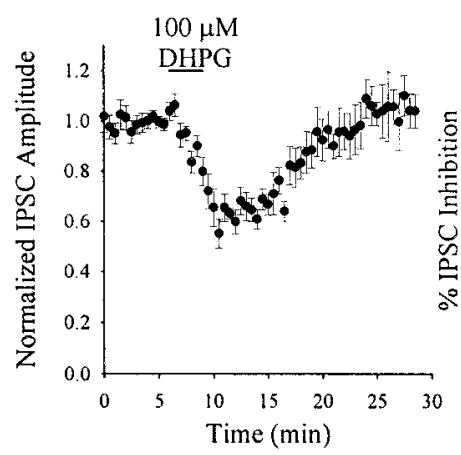

$\mathrm{C}$

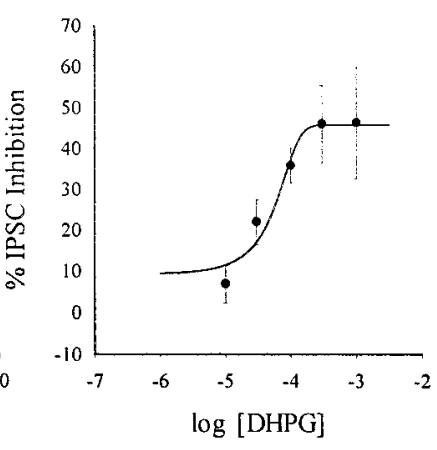

Figure 9. Activation of group I mGluRs decrease inhibitory transmission in the SNr. $A$, Representative traces of evoked IPSCs before (predrug), during (DHPG), and after washout of a brief bath application of $100 \mu \mathrm{M}$ DHPG. $B$, Average time course of the effect of $100 \mu \mathrm{M}$ DHPG; each point represents the mean $\pm \mathrm{SEM}$ of data from five cells. $C$, Dose-response relationship of DHPG-induced suppression of IPSCs. Each point represents the mean \pm SEM of three to four experiments.

inhibitory synaptic transmission. If activation of group I mGluRs decreases inhibitory transmission in the $\mathrm{SNr}$, this combined with the direct excitatory effects described above would provide a mechanism whereby group I mGluR activation could exert a powerful excitatory influence on the SNr. We directly tested this hypothesis by recording IPSCs in $\mathrm{SNr}$ GABAergic projection neurons. IPSCs were evoked by stimulating within the $\mathrm{SNr}$ with bipolar stimulation electrodes $(0.4-12.0 \mu \mathrm{A}$ every $30 \mathrm{sec})$ and were recorded at a holding potential of $-50 \mathrm{mV}$ in the presence of AMPA (CNQX; 10-20 $\mu \mathrm{M}$ ) and NMDA (D-AP-5; 10-20 $\mu \mathrm{M}$ ) receptor antagonists to prevent excitatory synaptic transmission. Bicuculline (10 $\mu \mathrm{M} ; n=8)$ abolished evoked IPSCs in all cells tested, confirming that the evoked currents were $\mathrm{GABA}_{\mathrm{A}}$ receptor-mediated responses. Short $(3 \mathrm{~min})$ bath application of the group I mGluR-selective agonist DHPG $(100 \mu \mathrm{M})$ reduced the amplitude of evoked IPSCs in a reversible manner (Fig. $9 A, B)$. Concentration-response analysis revealed that the inhibition of IPSCs by DHPG was concentration dependent. The relationship was fit with a Hill equation that gave an $\mathrm{EC}_{50}$ value of $30 \mu \mathrm{M}$ and Hill slope of 1.1. (Fig. 9C). This is consistent with the potency of DHPG on group I mGluRs.

Pharmacological studies of the DHPG-induced decrease in inhibitory transmission using subtype-selective antagonists were performed to determine which group I mGluR subtypes mediate this effect. The mGluR5-selective antagonist MPEP $(10 \mu \mathrm{M})$ had a slight tendency to block the DHPG-induced effect, but the response to MPEP did not reach statistical significance $(n=8$; $p>0.05 ; t$ test) (Fig. 10B,E). In contrast, the mGluR-selective antagonist CPCCOEt induced a significant reduction of the DHPG-induced suppression of IPSCs $(n=8$; $p<0.05$; $t$ test $)$ (Fig. 10C,E). However, the response to CPCCOEt was only a partial blockade of the response, and DHPG still induced a

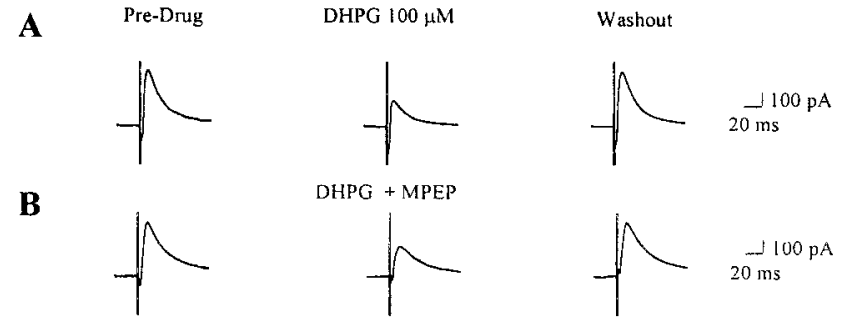

C

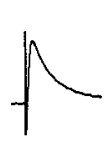

$\mathrm{DHPG}+\mathrm{CPCCOEt}$
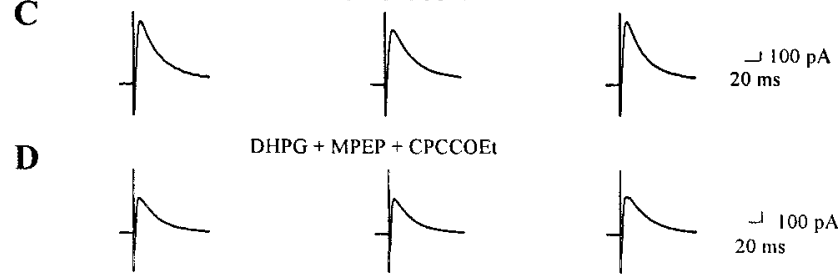

$\mathrm{DHPG}+\mathrm{MPEP}+\mathrm{CPCCOE}$

E
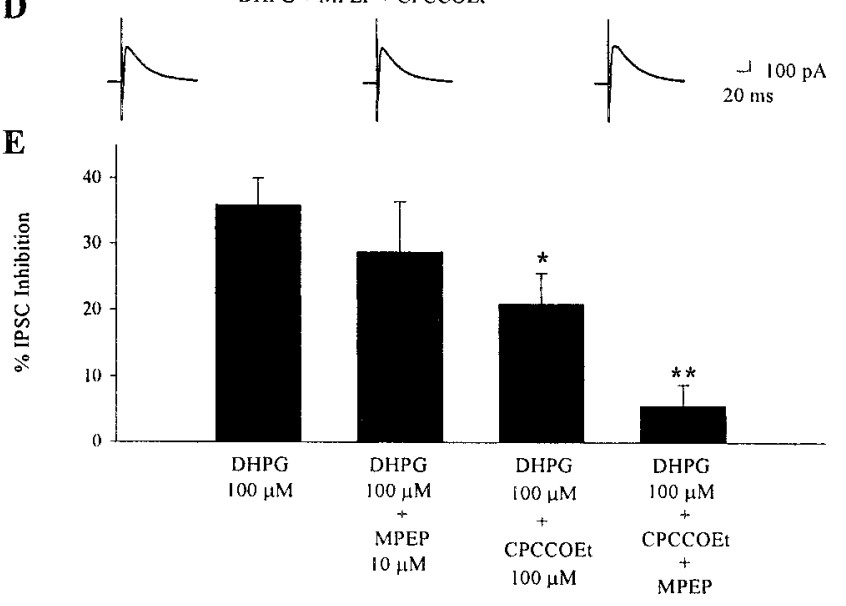

Figure 10. The group I mGluR-mediated decrease in inhibitory transmission involves both mGluR1 and mGluR5. $A-D$, Traces of evoked IPSCs before (control), during, and after (Washout) bath application of DHPG alone $(A)$ or in the presence of selective antagonists $(B-D)$. Selective antagonists include $10 \mu \mathrm{M}$ MPEP (mGluR5 selective; $B$ ) and $100 \mu \mathrm{M}$ CPCCOEt (mGluR1 selective; $C$ ) and the combination of both (D). E, Bar graph showing the average effect of selective antagonists on the DHPG-induced inhibition of IPSCs. Each bar represents the mean \pm SEM of data collected from eight cells. ${ }^{*} p<0.05 ;{ }^{*} p<0.01$.

$20.9 \pm 4.6 \%$ inhibition of IPSCs in the presence of this antagonist. Because neither antagonist was capable of completely blocking the response when added alone, we also determined the effect of a combination of both CPCCOEt and MPEP. The combination of antagonists completely blocked the ability of DHPG to reduce evoked IPSCs $(n=8 ; p<0.01)$ (Fig. 10D,E), suggesting that both mGluR1 and mGluR5 may participate in regulation of IPSCs in $\mathrm{SNr}$.

\section{The group I mGluR-mediated decrease in inhibitory transmission occurs by a presynaptic mechanism}

To determine whether the group I mGluR-mediated decrease in inhibitory transmission in the $\mathrm{SNr}$ is mediated through a presynaptic mechanism, we determined the effect of maximal concentrations of DHPG on frequency and amplitude of spontaneous mIPSCs. All mIPSC recordings were preformed at a holding potential of $-80 \mathrm{mV}$ in the presence of CNQX $(10-20 \mu \mathrm{M})$ and D-AP-5 $(10-20 \mu \mathrm{M})$ to block glutamatergic synaptic currents and $1 \mu \mathrm{M}$ TTX to block activity-dependent release of transmitter. mIPSCs were measured as inward currents with pipettes in which $\mathrm{Cl}^{-}(140 \mathrm{~mm})$ was the major anion in the internal solution.

Application of the group I selective agonist DHPG $(100 \mu \mathrm{M})$ had no significant effect on mIPSC frequency or amplitude (Fig. 
Pre-Drug

$\mathbf{A}$

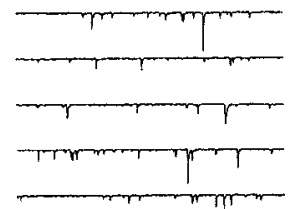

B

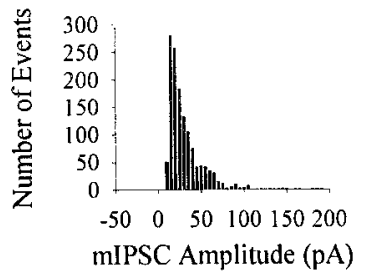

C

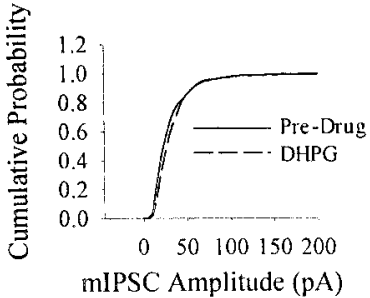

D

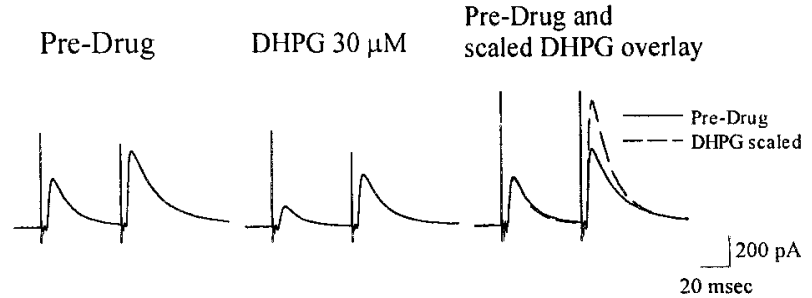

Figure 11. Inhibition of IPSCs induced by the activation of group I mGluRs is mediated by a presynaptic mechanism. $A$, Examples of mIPSC traces before (predrug) and during application of $100 \mu \mathrm{M}$ DHPG. $B$, Amplitude histograms of mIPSCs before (left) and during (right) application of $100 \mu \mathrm{M}$ DHPG. $C$, Cumulative probability plots showing a lack of effect of DHPG on mIPSC amplitude (left) (Kolmogorov-Smirnov; $p>0.05$ ) and interevent interval (right) (Kolmogorov-Smirnov; $p>$ $0.05)$. Data shown are pooled from four experiments. $D$, Traces of paired-pulse experiments before (Pre-drug) and during application of 30 $\mu \mathrm{M}$ DHPG. On the right, an overlay of the predrug trace (straight line) and a trace during application of DHPG scaled to the amplitude of the first IPSC (dashed line) is shown. DHPG increases the ratio of paired-pulse facilitation in five of six cells.

$11 A, B)$. This can be seen as a failure to induce a significant shift in the amplitude or interevent interval cumulative probability plots (amplitude, Kolmogorov-Smirnov, $p>0.05, n=4$; frequency, Kolmogorov-Smirnov, $p>0.05, n=4$ ) (Fig. 11B). The average mIPSC frequency before drug application was $1.74 \pm 0.4$ and $1.40 \pm 0.4 \mathrm{~Hz}$ after application of $100 \mu \mathrm{M}$ DHPG $(p>0.05$; $n=4)$. The average mIPSC amplitude was $29.3 \pm 4.2 \mathrm{pA}$ before and $31.9 \pm 3.5 \mathrm{pA}$ after DHPG application $(p>0.05 ; n=4)$. This lack of an effect on mIPSC amplitude and frequency is consistent with a presynaptic site of action for the group I mGluR-mediated suppression of synaptic transmission (Parfitt and Madison, 1993; Doze et al., 1995; Gereau and Conn, 1995b; Scanziani et al., 1995; Bradley et al., 2000). To further test this hypothesis, we also determined the effect of DHPG on pairedpulse facilitation of evoked IPSCs. All paired-pulse recordings were made in the presence of CNQX (10-20 $\mu \mathrm{M})$ and D-AP-5 $(10-20 \mu \mathrm{M})$ with standard internal solution to allow measurement of outward IPSCs. IPSCs were evoked every $30 \mathrm{sec}$ by paired stimulations of equal strength with a $50 \mathrm{msec}$ interpulse interval. At these intervals, paired-pulse facilitation was observed in all recordings $(60.2 \pm 6.3 \% ; n=11)$. Only cells that showed an agonist-induced inhibition of the amplitude of the first IPSC of at least $25 \%$ were used for analysis. DHPG $(30 \mu \mathrm{M})$ induced an increase in paired-pulse facilitation (Fig. 11D) in five of six cells examined. In those cells, the average increase in paired-pulse facilitation induced by DHPG was $56.1 \pm 11.7 \%(p<0.05 ; n=$ $5)$ over the facilitation seen in the absence of DHPG.

Together, these studies suggest that activation of the group I mGluRs mGluR1 and mGluR5 reduce inhibitory transmission in the $\mathrm{SNr}$ through a presynaptic mechanism. Furthermore, this decrease in GABAergic inhibition may combine with the direct postsynaptic excitatory effects of mGluR1 activation to produce a powerful excitation of this crucial basal ganglia output nucleus.

\section{DISCUSSION}

The data presented here demonstrate that activation of group I mGluRs produces an excitation of the SNr. Both mGluR1 and mGluR5 are found at postsynaptic sites in the $\mathrm{SNr}$ and are sparsely localized in unmyelinated axons and putative GABAergic axon terminals in this region. Activation of group I mGluRs produces an excitation of SNr neurons by two distinct mechanisms. Activation of postsynaptically localized group I mGluRs on SNr GABAergic neurons produces a robust depolarization that induces a marked increase in action potential firing. The depolarization is accompanied by a decrease in membrane conductance, and the underlying current has a reversal potential consistent with mediation by inhibition of a leak potassium channel. Furthermore, this effect is attributable to selective activation of mGluR1 and can be produced by synaptically released glutamate. Activation of group I mGluRs also induces a decrease in inhibitory transmission in the SNr. This effect is mediated by both mGluR1 and mGluR5 and occurs through a presynaptic mechanism.

Because the glutamatergic projection from the STN provides a large proportion of excitatory terminals on SNr GABAergic neurons, it is likely that the primary source of glutamate acting on group I mGluRs is released from STN afferents. However, several other regions, including the pedunculopontine nucleus (Charara et al., 1996) and the nucleus raphe (Corvaja et al., 1993), provide a sparse projection accounting for a small percentage of asymmetric terminals in the SNr. Therefore, group I mGluRs may also modulate these inputs. Interestingly, although both mGluR1 and mGluR5 are postsynaptically localized in SNr neurons, our pharmacological studies demonstrate that activation of mGluR1 is solely responsible for the group I-mediated depolarization. This is of interest because both mGluR1 and mGluR5 couple to phosphoinositide hydrolysis and are capable of inducing depolarization of other neuronal populations (for review, see Conn and Pin, 1997; Anwyl, 1999). A potential explanation of this may be provided by recent immunogold studies examining the subcellular localization of the group I mGluRs in SNr (Hubert et al., 2001). This study observed that mGluR1a immunoreactivity is predominately associated with the membrane. In contrast, $>80 \%$ of mGluR5 immunoreactivity was localized to a cytoplasmic compartment. Thus, specificity of function may be produced by differences in subsynaptic localization or some other functional segregation of these receptors. It should be noted that, whereas mGluR1 plays the predominate role in mediating the group I mGluR-induced depolarization in the SNr, mGluR5 may play 
important physiological roles regulating cell properties that were not measured in the present study. For example, group I mGluRs are known to modulate NMDA receptor currents in a variety of brain regions, and it is possible that mGluR5 is involved in a similar modulation in SNr. Future studies on the role of mGluR5 in these cells may provide important insight into the distinct functional roles of closely related receptor subtypes within a single neuronal population.

In addition to the postsynaptic labeling of neurons in the $\mathrm{SNr}$ for both group I mGluR subtypes, we also detected presynaptic staining. Consistent with this, we found that activation of presynaptic group I mGluRs decreases inhibitory transmission. The results of both the paired-pulse experiments and the analysis of mIPSCs strongly suggest that the group I mGluR-mediated decrease in IPSCs has a presynaptic mechanism of action, yet the relatively sparse staining detected in inhibitory terminals appears unlikely to be sufficient to mediate this response. The more abundant axonal staining may represent group I mGluRs on preterminal axons of GABAergic neurons, which could mediate the observed decrease in inhibitory transmission. It should be noted that this distribution is reminiscent of previous reports of mGluR2/3 distribution in preterminal axons at sites distant from the synapse (Lujan et al., 1997). On the other hand, the finding that the decrease in inhibitory transmission has a presynaptic locus does not necessarily require that the receptor mediating this response is localized presynaptically. For example, in the CA1 region of the hippocampus, depolarization of CA1 pyramidal neurons induces the release of a putative retrograde transmitter that decreases inhibitory transmission through a presynaptic mechanism (Alger et al., 1996). Our current experiments do not allow us to distinguish between such a mechanism and an action of DHPG on a presynaptically localized receptor.

The finding that group I mGluRs both directly excite and disinhibit SNr neurons is of particular interest for understanding the role the STN plays in modulation of the SNr. The indirect pathway is composed of striatal projections through the globus pallidus and the STN, which constitute a large percentage of excitatory terminals on SNr GABAergic neurons (Smith et al., 1998). Although the glutamatergic input to the $\mathrm{SNr}$ is sparse, it plays a critical role in basal ganglia functions, as evidenced by the pronounced clinical effects of STN lesions in PD (Guridi and Obeso, 1997). The STN also plays a key role in the pathological activity of the SNr. Transition of STN neurons from single-spike activity to burst-firing mode and resultant over excitation of the $\mathrm{SNr}$ has been implicated in the pathophysiology of PD (Hollerman and Grace, 1992; Bergman et al., 1994; Hassani et al., 1996), as well as some forms of epilepsy (Deransart et al., 1998). Furthermore, STN neurons exhibit extremely high firing rates and can typically exceed $25-50 \mathrm{~Hz}$ during burst-firing mode (Hollerman and Grace, 1992; Bergman et al., 1994; Wichmann et al., 1994; Beurrier et al., 1999; Bevan and Wilson, 1999). The robust excitatory effects of mGluR1 activation described here could play an important role in the powerful control exerted by the relatively sparse glutamatergic input to this nucleus from the STN.

Our current findings add to a growing body of literature suggesting that group I mGluRs play important roles in regulating functions of basal ganglia circuits (for review, see Smith et al., 2000, 2001; Conn et al., 2001; Rouse et al., 2001). For instance, mGluR5 is heavily expressed in the striatum and is also present at lower levels in the STN and the pallidal complex (Testa et al., 1994, 1995; Kerner et al., 1997; Tallaksen-Greene et al., 1998; Hanson and Smith, 1999). Although the levels of mGluR1 mRNA are more limited, this receptor is also found throughout the basal ganglia (Testa et al., 1994; Kerner et al., 1997; Tallaksen-Greene et al., 1998; Hanson and Smith, 1999). A number of studies suggest that agonists of group I mGluRs may act at several levels to increase the net activity of projection neurons in basal ganglia. For instance, activation of group I mGluRs potentiates NMDA receptor currents in striatal neurons (Colwell and Levine, 1994; Pisani et al., 1997). Furthermore, behavioral studies combined with studies of changes in 2-deoxyglucose uptake and Fos immunoreactivity suggest that injection of group I mGluR agonists in the striatum induces a selective activation of the indirect pathway from the striatum and thereby increases activity of the output nuclei (Kaatz and Albin, 1995; Kearney et al., 1997). In addition, recent physiological studies suggest that activation of group I mGluRs has profound excitatory effects on STN projection neurons (Abbott et al., 1997; Awad and Conn, 1999). These previous studies together with the present data suggest that group I mGluRs function at three major sites to increase overall output of the basal ganglia motor circuit.

\section{REFERENCES}

Abbott A, Wigmore MA, Lacey MG (1997) Excitation of rat subthalamic nucleus neurones in vitro by activation of a group I metabotropic glutamate receptor. Brain Res 766:162-167.

Alger BE, Pitler TA, Wagner JJ, Martin LA, Morishita W, Kirov SA, Lenz RA (1996) Retrograde signalling in depolarization-induced suppression of inhibition in rat hippocampal CA1 cells. J Physiol (Lond) 496:197-209.

Annoura H, Fukunaga A, Uesugi M, Tatsouka T, Horikawa Y (1996) A novel class of antagonists for metabotropic glutamate receptors, 7-(hydroxyimino)cyclopropchromen-1a-carboxylates. Bioorg Med Chem Lett 6:763-766.

Anwyl R (1999) Metabotropic glutamate receptors: electrophysiologica properties and role in plasticity. Brain Res Brain Res Rev 29:83-120.

Awad H, Conn PJ (1999) Regulation of neurons of thesubthalamic nucleus by metabotropic glutamate receptors. Soc Neurosci Abstr 25:176.15

Bergman H, Wichmann T, Karmon B, DeLong MR (1994) The primate subthalamic nucleus. II. Neuronal activity in the MPTP model of parkinsonism. J Neurophysiol 72:507-520.

Beurrier C, Congar P, Bioulac B, Hammond C (1999) Subthalamic nucleus neurons switch from single-spike activity to burst-firing mode. J Neurosci 19:599-609.

Bevan MD, Wilson CJ (1999) Mechanisms underlying spontaneous oscillation and rhythmic firing in rat subthalamic neurons. J Neurosci 19:7617-7628.

Bolam JP, Smith Y (1990) The GABA and substance P input to dopaminergic neurones in the substantia nigra of the rat. Brain Res 529:57-78.

Bowes M, Panesar M, Gentry C, Urban L, Gasparini F, Kuhn R, Walker K (1999) Anti-hyperalgesic effects of the novel metabotropic glutamate receptor 5 antagonists 2-methyl-6-(phenylethynyl)-pyridine, in rat models of inflammatory pain. Br J Pharmacol 125:250.P.

Bradley SR, Standaert DG, Rhodes KJ, Rees HD, Testa CM, Levey AI, Conn PJ (1999a) Immunohistochemical localization of subtype 4a metabotropic glutamate receptors in the rat and mouse basal ganglia J Comp Neurol 407:33-46.

Bradley SR, Standaert DG, Levey AI, Conn PJ (1999b) Distribution of group III mGluRs in rat basal ganglia with subtype-specific antibodies. Ann NY Acad Sci 868:531-534.

Bradley SR, Marino MJ, Wittmann M, Rouse ST, Awad H, Levey AI, Conn PJ (2000) Activation of group II metabotropic glutamate receptors inhibits synaptic excitation of the substantia nigra pars reticulata. J Neurosci 20:3085-3094.

Casabona G, Knopfel T, Kuhn R, Gasparini F, Baumann P, Sortino MA Copani A, Nicoletti F (1997) Expression and coupling to polyphosphoinositide hydrolysis of group I metabotropic glutamate receptors in early postnatal and adult rat brain. Eur J Neurosci 9:12-17.

Charara A, Smith Y, Parent A (1996) Glutamatergic inputs from the pedunculopontine nucleus to midbrain dopaminergic neurons in primates: Phaseolus vulgaris-leucoagglutinin anterograde labeling combined with postembedding glutamate and GABA immunohistochemistry. J Comp Neurol 364:254-266.

Clark BP, Baker R, Goldsworthy J, Harris JR, Kingston AE (1997) (+)-2-methyl-4-carboxyphenylglycine (LY367385) selectively antagonises metabotropic glutamate mGluR1 receptors. Bioorg Med Chem Lett 7:2777-2780. 
Colwell CS, Levine MS (1994) Metabotropic glutamate receptors modulate $N$-methyl-D-aspartate receptor function in neostriatal neurons. Neuroscience 61:497-507.

Conn PJ, Pin JP (1997) Pharmacology and functions of metabotropic glutamate receptors. Annu Rev Pharmacol Toxicol 37:205-237.

Conn PJ, Awad H, Bradley SR, Marino MJ, Rouse ST, Wittman M (2001) Physiological roles of multiple metabotropic glutamate receptor subtypes in the rat basal ganglia. In: Basal ganglia and thalamus in health and movement disorders (Ilinsky I, Kultas-Ilinsky K, eds), pp 151-162. New York: Kluwer.

Corvaja N, Doucet G, Bolam JP (1993) Ultrastructure and synaptic targets of the raphe-nigral projection in the rat. Neuroscience 55:417-427.

Crepel V, Aniksztejn L, Ben Ari Y, Hammond C (1994) Glutamate metabotropic receptors increase a $\mathrm{Ca}^{2+}$-activated nonspecific cationic current in CA1 hippocampal neurons. J Neurophysiol 72:1561-1569.

Deransart C, Vercueil L, Marescaux C, Depaulis A (1998) The role of basal ganglia in the control of generalized absence seizures. Epilepsy Res 32:213-223.

Doze VA, Cohen GA, Madison DV (1995) Calcium channel involvement in GABAB receptor-mediated inhibition of GABA release in area CA1 of the rat hippocampus. J Neurophysiol 74:43-53.

Fiorillo CD, Williams JT (1998) Glutamate mediates an inhibitory postsynaptic potential in dopamine neurons. Nature 394:78-82.

Gasparini F, Lingenhoel K, Flor PJ, Munier N, Heinrich M, Pagano A, Vranesic I, Biollaz M, Keckendom R, Allgeiger H, Varney M, Johnson E, Hess SD, Velicelebi G, Kuhn R, Urban L (1999) 2-methyl-6(phenylethynyl)-pyridine (MPEP): a novel potent, subtype-selective and systemically active antagonist at metabotropic glutamate receptor subtype 5. Br J Pharmacol 125:154.P.

Gereau RW, Conn PJ (1995a) Roles of specific metabotropic glutamate receptor subtypes in regulation of hippocampal CA1 pyramidal cell excitability. J Neurophysiol 74:122-129.

Gereau RW, Conn PJ (1995b) Multiple presynaptic metabotropic glutamate receptors modulate excitatory and inhibitory synaptic transmission in hippocampal area CA1. J Neurosci 15:6879-6889.

Guerineau NC, Gahwiler BH, Gerber U (1994) Reduction of resting K+ current by metabotropic glutamate and muscarinic receptors in rat $\mathrm{CA} 3$ cells: mediation by G-proteins. J Physiol (Lond) 474:27-33.

Guerineau NC, Bossu JL, Gahwiler BH, Gerber U (1995) Activation of a nonselective cationic conductance by metabotropic glutamatergic and muscarinic agonists in CA3 pyramidal neurons of the rat hippocampus. J Neurosci 15:4395-4407.

Guridi J, Obeso JA (1997) The role of the subthalamic nucleus in the origin of hemiballism and parkinsonism: new surgical perspectives. Adv Neurol 74:235-247.

Hanson JE, Smith Y (1999) Group I metabotropic glutamate receptors at GABAergic synapses in monkeys. J Neurosci 19:6488-6496.

Hassani OK, Mouroux M, Feger J (1996) Increased subthalamic neuronal activity after nigral dopaminergic lesion independent of disinhibition via the globus pallidus. Neuroscience 72:105-115.

Hausser M, Stuart G, Racca C, Sakmann B (1995) Axonal initiation and active dendritic propagation of action potentials in substantia nigra neurons. Neuron 15:637-647.

Hollerman JR, Grace AA (1992) Subthalamic nucleus cell firing in the 6-OHDA-treated rat: basal activity and response to haloperidol. Brain Res 590:291-299.

Hubert GW, Paquet M, Smith Y (2001) Differential subcellular localization of mGluR1a and mGluR5 in the rat and monkey substantia nigra. J Neurosci 21:1838-1847.

Kaatz KW, Albin RL (1995) Intrastriatal and intrasubthalamic stimulation of metabotropic glutamate receptors: a behavioral and Fos immunohistochemical study. Neuroscience 66:55-65.

Kearney JA, Frey KA, Albin RL (1997) Metabotropic glutamate agonist-induced rotation: a pharmacological, FOS immunohistochemical, and $\left[{ }^{14} \mathrm{C}\right]$-2-deoxyglucose autoradiographic study. J Neurosci 17:4415-4425.

Kerner JA, Standaert DG, Penney Jr JB, Young AB, Landwehrmeyer GB (1997) Expression of group one metabotropic glutamate receptor subunit mRNAs in neurochemically identified neurons in the rat neostriatum, neocortex, and hippocampus. Brain Res Mol Brain Res 48:259-269.

Kingston AE, Ornstein PL, Wright RA, Johnson BG, Mayne NG, Burnett JP, Belagaje R, Wu S, Schoepp DD (1998) LY341495 is a nanomolar potent and selective antagonist of group II metabotropic glutamate receptors. Neuropharmacology 37:1-12.

Kosinski CM, Standaert DG, Testa CM, Penney Jr JB, Young AB (1998) Expression of metabotropic glutamate receptor 1 isoforms in the substantia nigra pars compacta of the rat. Neuroscience 86:783-798.

Kosinski CM, Bradley SR, Conn PJ, Levey AI, Landwehrmeyer GB, Penney Jr JB, Young AB, Standaert DG (1999) Localization of metabotropic glutamate receptor $7 \mathrm{mRNA}$ and $\mathrm{mGluR} 7 \mathrm{a}$ protein in the rat basal ganglia. J Comp Neurol 415:266-284.
Litschig S, Gasparini F, Rueegg D, Stoehr N, Flor PJ, Vranesic I, Prezeau L, Pin JP, Thomsen C, Kuhn R (1999) CPCCOEt, a noncompetitive metabotropic glutamate receptor 1 antagonist, inhibits receptor signaling without affecting glutamate binding. Mol Pharmacol 55:453-461.

Lujan R, Roberts JD, Shigemoto R, Ohishi H, Somogyi P (1997) Differential plasma membrane distribution of metabotropic glutamate receptors $\mathrm{mGluR} 1$ alpha, $\mathrm{mGluR} 2$ and $\mathrm{mGluR} 5$, relative to neurotransmitter release sites. J Chem Neuroanat 13:219-241.

Mannaioni G, Attucci S, Missanelli A, Pellicciari R, Corradetti R, Moroni F (1999) Biochemical and electrophysiological studies on $(S)-(+)-2$ (3'-carboxybicyclo[1.1.1]pentyl)-glycine (CBPG), a novel mGlu5 receptor agonist endowed with mGlu1 receptor antagonist activity. Neuropharmacology 38:917-926.

Marino MJ, Rouse ST, Levey AI, Potter LT, Conn PJ (1998) Activation of the genetically defined $\mathrm{m} 1$ muscarinic receptor potentiates $N$-methylD-aspartate (NMDA) receptor currents in hippocampal pyramidal cells. Proc Natl Acad Sci USA 95:11465-11470.

Martin LJ, Blackstone CD, Huganir RL, Price DL (1992) Cellular localization of a metabotropic glutamate receptor in rat brain. Neuron 9:259-270.

Miller LD, Petrozzino JJ, Connor JA (1995) G-protein-coupled receptors mediate a fast excitatory postsynaptic current in CA3 pyramidal neurons in hippocampal slices. J Neurosci 15:8320-8330.

Monn JA, Valli MJ, Massey SM, Wright RA, Salhoff CR, Johnson BG, Howe, T, Alt CA, Rhodes GA, Robey RL, Griffey KR, Tizzano JP Kallman MJ, Helton DR, Schoepp DD (1997) Design, synthesis, and pharmacological characterization of $(+)$-2-aminobicyclo[3.1.0]hexane2,6-dicarboxylic acid (LY354740): a potent, selective, and orally active group 2 metabotropic glutamate receptor agonist possessing anticonvulsant and anxiolytic properties. J Med Chem 40:528-537.

Nakanishi H, Kita H, Kitai ST (1987) Intracellular study of rat substantia nigra pars reticulata neurons in an in vitro slice preparation: electrical membrane properties and response characteristics to subthalamic stimulation. Brain Res 437:45-55.

Parfitt KD, Madison DV (1993) Phorbol esters enhance synaptic transmission by a presynaptic, calcium-dependent mechanism in rat hip pocampus. J Physiol (Lond) 471:245-268.

Petralia RS, Wang YX, Singh S, Wu C, Shi L, Wei J, Wenthold RJ (1997) A monoclonal antibody shows discrete cellular and subcellular localizations of mGluR1 alpha metabotropic glutamate receptors. J Chem Neuroanat 13:77-93.

Pisani A, Calabresi P, Centonze D, Bernardi G (1997) Enhancement of NMDA responses by group I metabotropic glutamate receptor activation in striatal neurones. Br J Pharmacol 120:1007-1014.

Richards CD, Shiroyama T, Kitai ST (1997) Electrophysiological and immunocytochemical characterization of GABA and dopamine neurons in the substantia nigra of the rat. Neuroscience 80:545-557.

Romano C, Sesma MA, McDonald CT, O'Malley K, Van den Pol AN, Olney JW (1995) Distribution of metabotropic glutamate receptor mGluR5 immunoreactivity in rat brain. J Comp Neurol 355:455-469.

Rouse ST, Marino MJ, Bradley SR, Awad H, Wittman M, Conn PJ (2001) Distribution and roles of metabotropic glutamate receptors in the basal ganglia motor circuit: implications for treatment of Parkinson's disease and related disorders. Pharmacol Ther 88:427-435.

Scanziani M, Gahwiler BH, Thompson SM (1995) Presynaptic inhibition of excitatory synaptic transmission by muscarinic and metabotropic glutamate receptor activation in the hippocampus: are $\mathrm{Ca}^{2+}$ channels involved? Neuropharmacology 34:1549-1557.

Schoepp DD, Goldsworthy J, Johnson BG, Salhoff CR, Baker SR (1994) 3,5-dihydroxyphenylglycine is a highly selective agonist for phosphoinositide-linked metabotropic glutamate receptors in the rat hippocampus. J Neurochem 63:769-772

Shigemoto R, Nakanishi S, Mizuno N (1992) Distribution of the mRNA for a metabotropic glutamate receptor (mGluR1) in the central nervous system: an in situ hybridization study in adult and developing rat. J Comp Neurol 322:121-135.

Shigemoto R, Nomura S, Ohishi H, Sugihara H, Nakanishi S, Mizuno N (1993) Immunohistochemical localization of a metabotropic glutamate receptor, mGluR5, in the rat brain. Neurosci Lett 163:53-57.

Smith Y, Bolam JP (1991) Convergence of synaptic inputs from the striatum and the globus pallidus onto identified nigrocollicular cells in the rat: a double anterograde labeling study. Neuroscience 44:45-73.

Smith Y, Bevan MD, Shink E, Bolam JP (1998) Microcircuitry of the direct and indirect pathways of the basal ganglia. Neuroscience $86: 353-387$.

Smith Y, Charara A, Hanson JE, Paquet M, Levey AI (2000) GABA and group I metabotropic glutamate receptors in the striatopallida complex in primates. J Anat 196:555-576.

Smith Y, Charara A, Paquet M, Kieval J, Pare J-F, Hanson JE, Hubert GW, Kuwajima M, Levey AI (2001) Ionotropic and metabotropic GABA and glutamate receptors in primate basal ganglia. J Chem Neuroanat 22:13-42.

Tallaksen-Greene SJ, Kaatz KW, Romano C, Albin RL (1998) Localization of mGluR1a-like immunoreactivity and mGluR5-like immuno- 
reactivity in identified populations of striatal neurons. Brain Res $780: 210-217$

Testa CM, Standaert DG, Young AB, Penney JB Jr (1994) Metabotropic glutamate receptor mRNA expression in the basal ganglia of the rat. J Neurosci 14:3005-3018.

Testa CM, Standaert DG, Landwehrmeyer GB, Penney Jr JB, Young AB (1995) Differential expression of mGluR5 metabotropic glutamate receptor mRNA by rat striatal neurons. J Comp Neurol 354:241-252.

Testa CM, Friberg IK, Weiss SW, Standaert DG (1998) Immunohistochemical localization of metabotropic glutamate receptors mGluR1a and mGluR2/3 in the rat basal ganglia. J Comp Neurol 390:5-19.

Wichmann T, DeLong MR (1997) Physiology of the basal ganglia and pathophysiology of movement disorders of basal ganglia origin. In: Movement disorders: neurological principals and practice (Watts RL, ed), pp 87-97. New York: McGraw-Hill.

Wichmann T, DeLong MR (1998) Models of basal ganglia function and pathophysiology of movement disorders. Neurosurg Clin $\mathrm{N}$ Am 9:223-236.

Wichmann T, Bergman H, DeLong MR (1994) The primate subthalamic nucleus. I. Functional properties in intact animals. J Neurophysiol 72:494-506.

Wittmann M, Marino MJ, Rouse ST, Conn PJ (2000) Metabotropic glutamate receptors modulate excitatory and inhibitory transmission in the substantia nigra pars reticulata. Soc Neurosci Abstr 26:740.15. 